\title{
Prerrogativas e sujeições da administração pública.
}

\author{
Cretella Júnior \\ Cateårático de Direito Administrativo da
Faculdade de Direito da Universidade de \\ São Paulo.
}

1. Posição singular da Administração. 2. A potestade pública. 3. Definição de "prerrogativas públicas". 4. A auto-executoriedade. 5. A desapropriação. 6. A requisição. 7. A auto-tutela. 8. A imunidade tributária. 9. As sujeições da Administração. 10. Regime jurídico das prerrogativas e sujeições da Administração.

\section{Posição singular da Administração.}

A pessoa pública ou pessoa jurídica pública opõe-se, na doutrina do direito, à pessoa privada ou pessoa jurídica privada. Não se confundem.

Diversos traços gerais e especiais assinalam a tipologia das primeiras, salientando-se, entre outros, alguns que são enumerados pelos autores: a criação, que depende de ato do Estado, jamais de iniciativa genética de direito privado; a inexistência de liberdade de adesão, ou seja, todo particular que preenche determinados requisitos de fato, passa a integrar a pessoa jurídica, por meio da adesão, como no caso em que, fixando-se domicilio numa circunscrição territorial, município, comuna, Estado-membro, passa-se automàticamente a pertencer à pessoa jurídica pública. A pertencialidade às circunscrições territoriais decorre das respectivas fixações domiciliares; a finalidade, que nunca é de 
ordem privada, mas de ordem pública, ou seja, a satisfação de interêsses públicos deverá estar sempre na base de qualquer ato ou providência do Estado, por meio da intervenção da pessoa pública que em seu nome age; a capacidade que, por mais variada que seja, ultrapassa de muito a paralela do direito privado, porque a pessoa jurídica pública dispõe de prerrogativas ou privilégios, decorrentes de seu poder de imperium, que lhe assegura posição singular no mundo juridico (Rivero Jean, Droit administratif, $4^{\mathrm{a}}{ }^{\mathrm{e}}$ ed., 1970, págs. 46-47; Vedel, Georges, Droit administratif, 4. ${ }^{\mathrm{a}}$ ed., 1968, pág. 559).

A doutrina francesa tem dedicado excelentes páginas ao tema, empregando os vocábulos puissance e pouvoir, o primeiro devendo ser traduzido pelo nosso potestade, que equivale ao italiano potestà e ao espanhol potestad, o segundo -pouvoir --, representado em nosso vocabulário comum e técnico-jurídico pelo têrmo poder.

Potestade é vocábulo clássico, em língua portuguêsa, que precisa ser ressuscitado, para traduzir com precisão a idéia contida em puissance.

Camões, por exemplo, usa a todo instante do têrmo potestade, como ocorre na conhecida passagem do gigante Adamastor: "Oh! potestade, disse, sublimada" (Lusíadas, V, 38. Cf. ainda III, 15; IX, 20; X, 98).

Tratando da puissance publique, que é a nossa potestade pública, escreve Rivero: “As relações entre particulares são baseadas na igualdade jurídica. Nenhuma vontade privada é, por natureza, superior a outra, a tal ponto que se imponha a esta contra sua vontade, o que ocorre porque o ato que caracteriza as relações privadas é o contrato, ou seja, o acôrdo de vontades. A Administração, entretanto, que deve satisfazer ao interêsse geral, não poderia atingir tal objetivo se estivesse no mesmo pé de igualdade com os particulares.

As vontades dos particulares, impulsionadas por móveis puramente pessoais, entrariam em choque com a vontade da 
Administração, tôda vez que esta lhes impusesse coações e sacrifícios exigidos pelo interêsse geral. A Administração recebeu, então, o poder de vencer tais resistências. Suas decjsões obrigam, sem que ela tenha de obter a aquiescência dos interessados. Além disso, a Administração tem o direito, não obstante a recalcitrância dos particulares, de persegui-los pela execução. Sob o nome, muito mal escolhido, mas tradicional, de puissance publique, é preciso entender o conjunto de prerrogativas de que é detentora a Administração para efetivar o interêsse geral" (Droit administratif, 4. ${ }^{\mathrm{a}}$ ed., 1970, pág. 11).

Em virtude do poder de império, imperium ou condição de potestade pública, inerente à pessoa jurídica, esta, na sua qualidade de poder público não se nivela à pessoa jurídica privada.

Parte do Estado - ou, o próprio Estado - , a pessoa jurídica pública ocupa na relação jurídico-administrativa um lugar todo especial e privilegiado, detentora que é de prerrogativas e de privilégios de potestade pública, inexistentes nas conotações que defluem da personalidade jurídica de direito privado.

\section{A potestade pública.}

Em fins do século passado e inicios dêste, o direito administrativo tem sido considerado como disciplina alicerçada na idéia matriz de potestade pública, empenhando-se a doutrina em construir a teoria dos atos de império e dos atos de gestão, que tanta polêmica despertou entre os publicistas.

A atividade de potestade pública era paralela à de ato de império — de "imperium" —, típica das operações do direito administrativo, quando intervinha o Estado, condicionado por um regime especial, derrogatório do direito comum, bastante diferente da atividade de direito privado, 
caracterizada por atos de gestão, regulados por um regime de direito privado.

"A atividade de potestade pública", argumentava-se, "é aquela em que os órgãos do Estado procedem por meio de ordens, interdições, regulamentações unilaterais, manifestando, em suma, uma vontade imperante. Os órgãos do Estado executam, assim, atos de potestade pública" (LAubadère André, Traité de droit administratif, $3^{\mathrm{a}}$ ed., 1963, vol. I, pág. 38). "Os atos praticados pela Administração, em virtude de seu poder de mando, a colocam fora do direito comum, porque não existem atos semelhantes, praticados por particulares" (Berthélemy Henri, Traité de droit administratif, 9a ed., 1920, pág. 1008).

Objeções de tôda sorte, feitas por Duguit, no Tratado (Dugurt Léon, Traité de droit constitutionnel, vol. II, pág. 263), e pelo Comissário Teissier, na clássica e metafísica distinção entre os atos jus imperii e os atos jus gestionis, não conseguiram abalar a noção de puissance publique, nem invalidar a série de prerrogativas que dela decorrem.

\section{Definição de "prerrogativas públicas".}

Empregada com acepção quase impossível de apreender-se, a expressão potestade pública ("puissance publique") é, na realidade, noção concreta e precisa, porque designa a situação tôda especial que cerca a Administração, dotando-a de atributos necessários e suficientes para conferir-lhe uma série de prerrogativas - e também de restrições ou de sujeições -, exorbitantes do direito comum, inexistentes nas pessoas jurídicas de direito privado.

A Administração pode e o particular não pode tomar uma série de medidas, quando sujeitos de uma relação jurídica; a Administração, entretanto, que desfruta de posição privilegiada na relação jurídica, está sujeita a inúmeras restrições ou imposições, ausentes nas relações jurídicas do direito privado. 
O vocábulo prerrogativa vem do latim prae $=$ antes, anterior, em primeiro lugar e rogativa, de rogare=rogar, questionar, votar, decidir. Privilégio vem do latim privus $=$ =particular, isolado, especial e lex, legis $=$ lei, norma jurídica.

Prerrogativa ou privilégio é o direito, poder de regalia que pessoa ou corporação usufrui mais do que outras, ou que as distinguem de outras que não os possuem (Caldas Aulete, Dicionário contemporâneo, "sub voce" prerrogativa).

Prerrogativa pública ou prerrogativa de potestade públi$c a$ é a posição especial em que fica a Administração, na relação jurídico-administrativa, derrogando o direito comum, ou, em outras palavras, é a faculdade especial conferida à Administração, quando se decide a agir contra o particular.

Pela condição favorável que a prerrogativa lhe confere, a Administração fica desnivelada ao particular, assumindo uma posição vertical, bem diversa da posição horizontal em que fica o particular diante do particular.

O quadro completo de prerrogativas e privilégios em que se localiza a Administração quando, na prática, concretiza medidas para realizar o interêsse público, delinea a potestade pública.

Da potestade pública ou potestas imperii advém a situação privilegiada da Administração, desnivelando-a diante do particular e tornando-a idônea para impor, em condição bastante vantajosa, sua vontade, em nome do interêsse público.

As prerrogativas públicas são as circunstâncias favoráveis ou propícias, que os sistemas jurídicos atribuem às pessoas jurídicas a fim de que, do melhor modo e com a maior economia possível, possam concretizar o interêsse público, mediante limitações impostas ao interêsse do particular.

Nem sempre, entretanto, a Administração usa processos impositivos para a efetivação do interêsse público. Quando, num processo expropriatório, fundado na necessidade pública, utilidade pública ou interêsse social, a vontade do Estado 
coincide com a do particular desapropriado, basta a figura do contrato, consubstanciada nas normas de um acôrdo, para a solução da vontade estatal. Não cabendo a utilização do acôrdo, repelido pelo expropriado, recorre a Administração ao instrumento adequado - a decisão unilateral expropriatória, traduzida, na prática, por uma série de medidas, inclusive manu militari.

O fundamento do regime jurídico das prerrogativas públicas é evidente. Nas relações jurídicas de particular a particular, impera a igualdade jurídica das partes. Situam-se no mesmo plano. Paralelizam-se. Ficam lado a lado. A vontade de uma das partes não supera, em momento algum, a vontade da outra. Por isso, a figura jurídica do contrato é suficiente para reger as vontades contrapostas dos contratantes, consubstanciando normas jurídicas de igual intensidade, sem favorecimentos.

Ao contrário, o objetivo da Administração é o de satisfazer os interêsses coletivos e, para a consecução dêstes, muitas vêzes se exige o sacrifício do particular, mediante uma série de limitações aos seus direitos.

A Administração ficaria inerte, paralisada, se cada vez que pretendesse movimentar-se, efetivando os atos administrativos editados, precisasse consultar os interêsses privados atingidos. Por isso, o Estado dotou os órgãos administrativos de um poder ou potestade para vencer a injustificada resistência do particular recalcitrante. As decisões administrativas, tomadas com vistas ao interêsse público, impõem-se sem prévia consulta ao administrado e, muitas vêzes, sem o título hábil expedido pelo Judiciário, como ocorre no âmbito do processo civil comum.

Pode a Administração, diante da resistência privada, fazer prevalecer, inclusive pelo emprêgo da fôrça, sua decisão, recorrendo a meios coativos e sufocando os esforços do particular impeditivos à consecução dos fins de interêsse público. 
Mediante atos unilaterais auto-executáveis, sem o correspondente título do Judiciário, a Administração interfere no cenário jurídico-administrativo, restringindo a esfera de direitos e interêsses do cidadão, sempre que o interêsse coletivo esteja afetado.

A potestade pública, o poder de império, revela-se no mundo jurídico de modo eficaz, visto cercar-se de prerrogalivas públicas, benefícios evidentes que reforçam sua atuação coativa no choque com o particular.

Na relação jurídico-administrativa, pois, a Administração é beneficiada com uma série de prerrogativas, que a colocam numa posição nitidamente favorável, quando comparada com a do particular que figura na mesma relação.

Entre as prerrogativas públicas, que dão relêvo todo especial ao regime jurídico da Administração, podemos citar a auto-executoriedade, a desapropriação, a requisição, a ocupação temporária, a auto-tutela, o poder impositivo.

Por outro lado, paradoxalmente, ao mesmo tempo que a $\Lambda$ dministração se caracteriza por ser detentora de "prerrogativas exorbitantes do direito comum", derrogações que podemos denominar de positivas ou favoráveis, é caracterizada por ser atingida por uma série de restrições ou sujeições, desvios que se apresentam como negativos ou desfavoráveis, desconhecidos pelo particular, quando em conflito com outro particular.

Dêsse modo, ao passo que o particular, pessoa física ou jurídica, pode tomar resoluções por motivos de natureza pessoal, afetiva (simpatia, antipatia, generosidade, capricho), desde que não contrariem princípios lícitos ou éticos, escolhendo seu pessoal ou fornecedores, sem nenhum critério, a não ser o da vontade, a Administração é presa ao interêsse público, sendo sujeita a procedimentos especiais, quer na escolha dos funcionários (concurso), quer na seleção dos fornecedores de gêneros ou serviços (concorrência pública). 
A potestade pública é o regime jurídico que se distingue, ao mesmo tempo, por prerrogativas e por sujeições, por máximos e mínimos, exorbitantes e derrogatórios do direito comum, recunhecidos e impostos a todos os que operam em nome e no exercício da soberania nacional (VEDEL Georges, Droit administratif, $4^{\text {a }}$ ed., 1968, pág. 19).

Pelas prerrogativas ou maximizações, que derrogam o direito comum, a Administração beneficia-se con prazos maiores, com amplitude de iniciativas, com providências que limitam a liberdade do particular.

Pelas sujeições ou minimizacõos, o administrador é obrigado a agir como órgão impessoal do poder público, impedindo que pretensões pessoais ou motivos de ordem privada interfiram na concretização dos direitos e deveres decorrentes da relação jurídico-administrativa.

As prerrogativas públicas põem em evidência o traço de império da Administração, desvinculada de qualquer idéia de pessoa humana e, pois, agindo de maneira impessoal, tendo em vista o bem público, a ordem pública, o interêsse público. As sujeições procuram impedir que o administrador, ao agir, leve para a vida pública seus traços de afetividade e caprichos, suas inclinações pessoais.

O fundamento último das prerrogativas públicas e das sujeições administrativas é um só - o da salvaguarda do interêsse público, objetivo precípuo do Estado. Salus reipublicae suprema lex esto.

Se o administrador não se ativesse às sujeições administrativas, deixaria de agir como órgão do Estado, prevaleceriam suas condições humanas. Os atos administrativos colimariam outros fins, que não os públicos. Estaria caracterizada a figura jurídica do desvio de poder.

\section{A auto-executoriedade.}

As decisões da Administração, decorrentes de sua potestas imperii, são auto-executáveis. A posição privilegia- 
da da Administração, diante do administrado, confere-lhe a faculdade excepcional de pôr em execução, com os próprios meios de que dispõe, os atos administrativos editados, sem a necessidade prévia de submeter tais pronunciamentos à apreciação da autoridade judiciária. é nisso que consiste a denominada auto-executoriedade do ato administrativo, também conhecida pelos nomes de privilégio de ação de ofício, privilégio da execução prévia, privilégio do prévio ou privilégio do preliminar ("privilège du préalable" on "privilège d'éxecution d'office").

Os atos administrativos são auto-execuláveis. Ato executório é o ato administralivo que passa a ter eficácia, imediatamente, que obriga por si, independentemente de sentença juảicial. A esta prerrogativa ou privilégio, que è a executoriedade, deve a Administração a faculdade de colocar-se em situação de vantagem diante do particular na prossecução do interêsse público. Pela auto-executoriedade o ato administrativo adquire fôrça especial que o impõe, diante do particular, independentemente de nova definição de direitos (CAETano Marcelo, Manual de direito administrativo, ed. brasileira de 1970, vol. I, pág. 409).

As decisões administrativas, que expressam a vontade do poder público, traduzida em atos administrativos, entram em ação, produzem efeitos imediatos, unilateralmente, sem a consulta ao particular ou o título expedido pelo magistrado judiciário.

A faculdade de exigir coativamente a observância dos próprios atos deriva do conceito de potestade pública, sendo-lhe inerente. Sem tal prerrogativa, o interêsse público ficaria equiparado e, por vêzes, preterido mesmo diante do interêsse privado, ao mesmo tempo que a vontade do Estado seria inoperante e inócua.

O caráter público de potestas administrativa matiza o ato executório, dando-lhe a fôrça necessária para atuar, realizando a aspiração de parte considerável da coletividade, da qual o Estado é intérprete e guardião. 
"A necessidade de manter a ordem pública exige, às vêzes, medidas materiais de execução rápida, que não se compadecem com a morosidade do processo judiciário, como, por exemplo, a remoção imediata de veículo que impeça o trânsito na via pública" (Duez Paul e Debeyre Guy, Traité de droit administratif, 1952, pág. 526).

A doutrina universal, principalmente a francesa e a italiana, tem dedicado excelentes páginas ao estudo do privilégio do preliminar, acompanhando o direito brasileiro, na doutrina e na jurisprudência, as grandes linhas traçadas pelos vários sistemas jurídicos.

O privilège du préalable, acolhido em nosso direito, fundamentou importante decisão do Tribunal de São Paulo, quando se firmou a tese de que a exigibilidade constitui qualidade inerente aos atos jurídico-administrativos, ou seja, a qualidade de produzir efeitos, de conformidade com o nêle constante, e nos têrmos previstos em lei.

No vasto e importante campo do poder de polícia, explicitado nos diversos ramos em que se desdobra a policia administrativa, a auto-executoriedade aparece com tôda sua fôrça, legitimando as providências rápidas do Poder Executivo, quando edita atos administrativos e imediatamente os faz atuar, no mundo jurídico.

Corolário do princípio setorial das prerrogativas públicas é, pois. o princípio do privilégio do preliminar ou da auto-executoriedade do ato administrativo, mediante o qual o ato administrativo, assim que editado pela autoridade competente, entra em execução, sem a necessidade de título hábil, expedido pelo Poder Judiciário.

\section{A desapropriação.}

O particular não pode desapropriar. Jamais, em qualquer sistema legislativo, entidade privada pode decretar desapropriações. Seria a subversão da ordem jurídica, visto que abriria a possibilidade de um particular atentar con- 
tra a propriedade privada. Por outro lado, é possível a promoção da desapropriação, que não se confunde com a decretação. Com base em texto legal autorizatório, por exemplo, uma concessionária pode providenciar as medidas que promovam a desapropriação.

A desapropriação é uma prerrogativa pública. É um privilégio de que gozam as pessoas jurídicas públicas políticas.

A prerrogativa pública expropriatória, traduzida no direito de expropriar, jusiifica a intervenção do Estado na ordem econômica, interferindo no direito de propriedade.

Em inúmeros casos, sintetizados em expressões que refletem a necessidade pública, a utilidade pública ou o interêsse social, a Administração é desnivelada - para melhor - do particular e beneficiada com uma posição de relêvo, na relação jurídico-administrativa.

Pela prerrogativa expropriatória a Administração tem a faculdade de apossar-se do bem privado, transmudando-o em bem público, em uma das três classes, a dos de uso comum, a dos de uso especial ou a dos dominicais.

O jus expropriandi é a prerrogativa pública que possibilita à Administração imitir-se no bem privado, móvel ou imóvel, sempre que o interêsse público o justifique.

o direito de expropriar decorre do traço de império que caracteriza a pessoa jurídica pública, detentora da potestade pública, da "puissance publique", ausente da pessoa física ou juridica, de direito privado.

É verdade, como acentuamos acima, que certos sistemas jurídicos admitem a possibilidade da intervenção das concessionárias de serviços públicos, numa determinada fase do processo expropriatório. Entre nós, entretanto, é bem clara a impossibilidade, sponte sua, de desapropriar, por parte das pessoas de direito privado.

Não dispondo da prerrogativa pública expropriatória, que é típica das pessoas juridicas públicas maiores, as emprêsas concessionárias, pessoas jurídicas de direito privado, 
têm a faculdade de promover, o privilégio da promoção expropriatória, não a prerrogativa de desapropriar.

Ora, promover não é desapropriar, promoção não é desapropriação.

Promoção é efetivação, é concretização, é operação complementar e auxiliar, bem distinta, inconfundível com o ato solene, volitivo e originário do Estado, consubstanciado na declaração. A declaração expropriatória é ato administrativo, regra geral originário do Poder Executivo, mas não há impedimento algum que tenha iniciativa no Poder Legislativo.

Prerrogativa do poder público, a declaração expropriatória é ato administrativo veiculado por lei ou por decreto, fazendo sua entrada no mundo jurídico, ao corporificar a vontade soberana do Estado.

As pessoas jurídicas públicas maiores, entre suas prerrogativas públicas, privilégios que lhes são inerentes e que decorrem de sua condição de entidades dotadas de potestade pública, incluem a prerrogativa expropriatória, faculdade coativa que lhes permite separar o proprietário de sua propriedade, transferida esta para o patrimônio do poder público expropriante ou colocada a serviço da coletividade.

A desapropriação, que é "a operação de direito público por meio da qual o Estado, necessitando de um bem particular para fins de interêsse público, obriga o proprietário a transferir-lhe a propriedade dêsse bem, mediante prévia e justa indenização, em dinheiro", só se justifica, no campo do direito, como instituto, diante do princípio da prerrogativa pública expropriatória, proposição setorial do direito administrativo, que fundamenta a medida extrema tomada pela Administração.

Corolário do princípio setorial das prerrogativas públicas, pois, a prerrogativa expropriatória é o direito que a Administração tem de interferir na propriedade privada, a- 
propriando-se de bens particulares, mediante o preenchimento de certos requisitos, prescritos em lei, desde que o interêsse público fundamente a decisão tomada.

\section{A requisiçãa.}

Ao lado da prerrogativa pública expropriatória delineia-se a prerrogativa pública requisitória, que configura o instituto da requisição.

Pela requisição, a Administração, numa operação unilateral de gestão pública, exige de uma pessoa a prestação de serviços, o fornecimento de objetos móveis, o abandono temporário do gôzo de imóveis ou de emprêsas para utilizá-los conforme o interêsse geral, num fim determinado (DuEz Paul e Debeyre Guy, Traité de droit administratif, 1952, pág. 859).

Requisição é o instituto jurídico especial, mediante o qual a Administração, pelo pagamento do equivalente, $\mathrm{em}$ dinheiro, usufrui, de modo definitivo ou transitório, o gôzo e uso da propriedade de bens móveis de que necessite ou que, por graves e urgentes necessidades públicas, não possa ou não queira adquirir, nas transações comuns, por meio das formas normais do contrato (Alessio Francesco, D' Istituzioni di diritto amministrativo, $4 .^{2}$ ed., 1949, vol. II, pág. 30).

Apoiando-se no sacrifício do particular, em prol do interêsse público, apresenta-se a requisição, na prática, como o processo unilateral da Administração, que objetiva a exigir do administrado a prestação de serviços ou a entrega de bens para a consecução de fins de interêsse público, mediante posterior e justa indenização, em dinheiro.

Prerrogativa da Administração, a requisição é medida extrema do poder público, providência de que o Estado lança mão em casos de calamidade pública, em momentos anômalos da vida nacional. 
Editado o ato requisitório, entra êle, imediatamente, em execução, por causa dos altos motivos que lhe deram origem.

Ora, o Estado é detentor dêsse privilégio ou prerrogati$v a$, em razão de sua potestade pública, que lhe faculta desnivelar-se do particular, alçar-se, assumir a posição soberana e incontrastável de mando, interferindo na propriedade privada por motivos relevantes.

Corolário do princípio setorial das prerrogativas públicas, pois, a prerrogativa requisitória, que oferece muitos pontos de analogia com a prerrogativa expropriatória, é o direito que a Administração tem de interferir na propriedade privada, apropriando-se de bens móveis (ou exigindo a prestação de serviços), mediante posterior e justa indenização, em dinheiro, sempre que o interêsse público o exija.

\section{A auto-tutela.}

A prerrogativa pública auto-tutelar, concretizada na figura juris denominada auto-tutela, vai refletir-se em todo o setor da polícia dos bens públicos.

Auto-tutelar é a prerrogativa pública que permite à Administração agir de modo direto, por si mesma, sem necessidade de recorrer à via judicial, a fim de efetuar a defesa do hem público, ameaçado ou violado, em sua integridade (turbação ou esbulho).

Pelo instituto de auto-tutela a Administração, dispensando a existência de texto de lei especial autorizativo, ou de título hábil, emitido pelo magistrado, age de modo imediato, valendo-se dos meios habituais, utilizados para a defesa da propriedade privada, agora dirigidos para a proteção da coisa pública.

Tal faculdade, concedida à Administração, constitui uma prerrogativa pública, um privilégio especialíssimo, verdadeira exceção no mundo do direito. 
Para a ocorrência da auto-tutela é preciso, antes de tudo, que seja incontestável a natureza pública do bem tutelado, repelidos, pois, quaisquer outros direitos de quem provoque o nascimento da atividade administrativa tutelar; em segundo lugar, é preciso que os bens tutelados sejam dominiais e nunca do domínio privado do Estado, caso em que se configuraria o desvio de poder (Marienhoff Miguel, S., Tratado del dominio publico, 1960, pág. 275 e Bozzi Aldo, Istituzioni di diritto pubblico, $2^{\mathrm{a}}$ ed., 1966, pág. 366).

Pela auto-tutela protege-se, não só a res, em sua constituição física, impedindo-se-lhe a degradação, o desgaste, a deterioração, como também se preserva o bem, contra o exercício de atos negativos de terceiros que pretendam danificá-lo. Por fim, a auto-tutela confere à Administração a faculdade de reaver, com os próprios meios, a coisa pública, retirando-a de quem a detenha ilegalmente. $O$ instituto da auto-tutela abrange as coisas imóveis e móveis, ambas integrantes do domínio público (Cretella Júnior José, Dos bens públicos no direito brasileiro, 1969, págs. 65-66).

Objetos preciosos dos museus, bem como livros e manuscritos das bibliotecas públicas devem ser auto-tutelados pela Administração e, quando passam às mãos de terceiros, de modo ilícito, ausente a vontade do Estado, exigem imediata recuperação.

"A peculiaridade do regime consiste no fato de que, enquanto os sujeitos privados tutelam a propriedade privada apenas por meio da ação judiciária, o Estado, ao contrário, tutela a propriedade dominial de maneira direta, mediante a atividade administrativa, pela polícia, ou melhor, pela polícia dos bens dominiais" (Alessi Renato, Sistema istituzionale del diritto amministrativo, 1953, pág. 405 e Tesauro Alfonso, Istituzioni di diritto pubblico, vol. II (Diritto amministrativo), 1951, pág. 448, Bonnard Roger, Précis de droit administratif, 1935, pág. 440). 
Não necessita a Administração de recorrer às ações possessórias, porque pode recuperar a posse perdida no próprio ano de sua perda, por si mesma, administrativamente (Álvarez-Gendin Sabino, Tratado general de derecho administrativo, 1958, vol. I, pág. 46 e BozzI Aldo, Istituzioni di diritto pubblico, $2^{\mathrm{a}}$ ed., 1966 , pág. 366 ), já que a propriedade dominial é defendida diretamente por meio de medidas de polícia e, indiretamente, por atos declaratórios da dominialidade (Romano Santi, Corso di diritto amministrativo, 1937. pág. 191).

A Administração conserva sua integridade diante dos particulares com os recursos de que dispõe o poder público. O conjunto dêsses meios cabe na idéia geral da polícia que, nesta aplicação particular, recebe o nome de polícia da coisa pública (MAYer Otto, Derecho administrativo alemán, tradução argentina, vol. III, pág. 150). É missão da polícia combater as perturbações que os particulares possam causar. Se a perturbação adquire o aspecto de ataque, estôrvo, dano ou obstáculo material, que emana da existência individual, a polícia responde com a coação direta, fazendo desaparecer a perturbação pelo uso da fôrça. É nisso que consiste a defesa administrativa (MAyer Otto, Derecho administrativo alemán, vol. III, pág. 144).

Esse emprêgo da fôrça é considerado um caso de coação policial direta, com a particularidade de que prescinde de fundamento legislativo específico que o autorize. Considera-se natural e encontra razão de ser na própria idéia de polícia. Enfim, para dar maior fôrça à proteção referida, a lei acrescenta sanções penais que castigam as infrações às diferentes ordens ou reprimem diretamente os fatos prejudiciais às coisas públicas (MAYER Otto, Derecho administrativo alemán, vol. III, págs. 150-151).

Na realidade, a polícia não trata, a rigor, das coisas, no sentido da conservá-las, mas concretiza-se em regras a serem observadas pelas pessoas a fim de prevenir-se a danifica- 
ção dos bens públicos (CaEtano Marcelo, Manual de direito administrativo, $7^{\mathrm{a}}$ ed., 1965, pág. 679).

Fica, dêsse modo, bem caracterizado o instituto da auto-tutela ou tutela administrativa dos bens públicos, cujo fundamento é o princípio setorial das prerrogativas públicas. Sem tal alicerce, a auto-tutela não subsistiria, visto erigir-se numa exceção, no cenário da polícia da propriedade, ou seja, numa iniciativa da Administração, desprotegida do respectivo título pelo Judiciário.

A Administração tem o direito e o dever de impedir que as coisas públicas pereçam, usando seus próprios meios para a proteção policial do domínio público.

Corolário do princípio setorial das prerrogativas públicas, pois, a prerrogativa autotutelar é a faculdade que tem a Administração de impedir a destruição e o uso da coisa pública, bem como a de reaver com os próprios meios policiais de que dispõe os bens do domínio público que tenham passado, ilegalmente, para as mãos do particular.

\section{A imunidade tributária.}

A prerrogativa pública tributária, derivada da potestas imperii do Estado, permite às pessoas jurídicas públicas competentes a exigência de tributos das pessoas privadas, físicas ou jurídicas.

O Estado, lato sensu, tem a faculdade impositiva, o poder de lançar impostos sôbre os mais diversos setôres do campo do direito privado. Entre nós, as pessoas jurídicas públicas, detentoras da competência impositiva, nas respectivas esferas de sua competência, podem tributar.

Tais pessoas são o Estado, em um de seus momentos, a Administração. Formam um conjunto de entes públicos que se situam em posição antagônica à dos particulares, que constituem o bloco dos entes privados. 
As pessoas jurídicas públicas estatais estão fora do campo dos entes tributáveis, protegidas aquelas pela prerrogativa da imunidade.

Imunidade é a prerrogativa pública que impossibilita, originàriamente, a incidência, em virtude de expressa vedação constitucional, configurando a impossibilidade do exercício do poder impositivo por parte da Administração, relativamente a certos e determinados fatos e pessoas.

A imunidade não se limita aos entes públicos maiores. Ao contrário, ultrapassando-os, atinge os entes públicos menores, como as autarquias, protegidas da incidência tributária, em virtude da prerrogativa pública que as alcança.

Compreende a imunidade tributária os impostos diretos e indiretos, caracterizando-se os entes dotados de personalidade juridica pública pelo traço marcante daquela prerrogativa pública que os coloca, desde o nascimento, num plano elevado, privilegiado, inatingido pela incidência.

Por outro lado, não se confunde imunidade com isenção, consistindo esta na omissão expressa do exercício da competência impositiva. $O$ ente público, em determinadas circunstâncias, desiste do poder impositivo. As pessoas privadas tributáveis, deixam de sê-lo "adquirindo" a condição, transitória ou permanente, da isenção. A imunidade, ao contrário, é atributo que adere ao ente, desde o nascimento. Nasce-se imune. A isenção adquire-se.

As pessoas jurídicas públicas são imunes a tributos. A prerrogativa da imunidade tributária é traço característico das pessoas jurídicas públicas maiores.

Não teria sentido que a Administração, que é o próprio Estado, necessitando de tributos para a consecução de seus fins, fôsse tributada, impondo-se a si mesma.

Além das pessoas públicas maiores, os entes públicos menores criados pelo Estado, como as autarquias, as fun- 
dações públicas e as corporações públicas, também se revestem da prerrogativa da imunidade tributária.

Dêsse modo, os serviços públicos descentralizados, as autarquias, em suas duas formas clássicas a fundação de direito público e a corporação de direito público, sempre com personalidade de direito público, explícita ou implìcitamente reconhecida por lei, estão equiparadas às pessoas jurídicas públicas maiores para efeitos da referida imunidade.

Corolário do principio setorial das prerrogativas públicas, pois, a prerrogativa da imunidade tributária é faculdade ou situação especial de que usufruem as pessoas jurídicas públicas, maiores ou menores, politicas ou administrativas, de serem imunes a tributos.

De outras vantagens ainda se beneficia a Administração, alicerçada no principio das prerrogativas públicas, tais como, por exemplo, a preriogativa dos prazos, situação que faculta ao Estado dispor de prazo em dôbro, quando participa de processo judicial, bem como de prazos especiais para a prescrição das ações, quando a Administração é parte; a prerrogativa de figurar como ré, o que transfere ao administrado, na posição de autor, a obrigação da produção de provas ("onus probandi incumbit auctori"); a prerrogativa da presunção da verdade e da legitimidade dos atos administrativos:

"O particular, devendo fazer cumprir, coativamente, um ato jurídico, deve demonstrar sua legitimidade. Para isso, precisa de um ato preventivo do juiz, que ateste e declare a legitimidade de sua pretensão. $O$ ato administrativo, ao contrário, se presume legítimo e, pois, tal ação declarativa é dispensada. Tratando-se de presunção relativa, admite-se prova em contrário, mas a formação de tal prova não pode retardar a execução do ato e influi apenas sôbre os efeitos de tal execução e sôbre a obrigação da Administração de indenizar o dano e de reparar, se possível, a ile- 
gitimidade" (ZANoBINI Guido, Corso di diritto amministrativo 6. ${ }^{\mathrm{a}}$ ed., 1950, vol. I pág. 236).

"Diz-se, comumente, que os atos administrativos são assistidos por uma presunção de legitimidade, isto é, de validade “(Alessio Francesco D', Istituzioni di diritto amministrativo italiano, $4 .^{\mathrm{a}}$ ed., 1949, vol. II, pág. 216).

Os atos administrativos, emanados de qualquer dos órgãos do Estado, são assistidos por uma presunção de legitimidade. Por isso, costuma dizer-se que os atos administrativos determinam uma situação aparente de direito em favor de terceiros de boa fé que tenham fundado sôbre tal presunção os seus direitos "(Ranelletri Oreste, Teoria degli atti amministrativi speciali, 7. ${ }^{\text {a }}$ ed., 1945, pág. 127).

A prerrogativa especial da Administração, de merecer tôda credibilidade, de editar atos, que se presumem legitimos, até que não intervenham outros atos administrativos que os declarem ilegítimos (Landi Guido e Potenza Giuseppe, Manuale di diritto amministrativo, 2. ${ }^{\mathrm{a}}$. ed., 1963, pág. 52 e Bozzi Aldo, Istituzioni di diritto pubblico, 2. ${ }^{a}$ ed., 1966, pág. 320 ), a coloca num plano de privilégio, em decorrência de sua característica de potestade pública.

Como conseqüência dessa prerrogativa, todos os atos da Administração, jurídicos ou não, todos os fatos administrativos, operações administrativas, providências, atos administrativos, fazem fé pública, são tidos como legítimos e verdadeiros, até prova em contrário.

A Administração não mente, não informa errôneamente, não induz ao êrro. Os atestados e certificados fornecidos pelos agentes do poder público merecem fé, são bons, gozam da presunção da veracidade e da legitimidade, até que não se demonstre o inverso. 


\section{As sujeições da Administração.}

Ao lado das prerrogativas públicas, que derivam da posição vertical que a Administração ocupa, em relação ao administrado, cumpre mencionar as sujeições, restrições ou limitações, traços negativos, verdadeiras capitis deminutiones, que atenuam o dinamismo da ação administrativa.

Sujeições administrativas são derrogações ou cargas peculiares ao regime jurídico público, mediante as quais a Administração é limitada em suas atividades, quando faz parte da relação jurídico-adiministrativa.

As pessoas privadas agem impelidas por interêsses particulares. O fim colimado é pessoal, íntimo e, desde que não seja ilícito, nem imoral, extravasa o campo da tutela jurídica.

"No direito privado, em geral, não se levam em conta os motivos pelos quais o agente (ou, nos negócios bilaterais, as partes) se decide a fazer a declaração e concretizar o negócio, porque, sejam quais forem os motivos individuais, fundados ou não, sejam ou não satisfatórios, existe sempre uma vontade que se encarnou no negócio jurídico, independentemente daqueles motivos. Os motivos não são elementos constitutivos do negócio jurídico. É o que impõe a tutela da boa fé das outras partes do negócio e na segurança das relações jurídicas. Assim, ao passo que o êrro na causa torna o negócio inválido, porque lhe falta um elemento essencial, o êrro dos motivos é, por princípio, juridicamente, irrelevante. Se o agente quer que os motivos determinantes do negócio tenham relevância, deve transportá-los para a declaração da vontade e apontá-los como condiçôes ou modos do próprio negócio “(RANELletTI Oreste, Teoria degli atti amministrativi speciali, $7^{\mathrm{a}}$ ed., 1945, pág. 71).

As pessoas jurídicas de direito público, que agem por intermédio de pessoas físicas, estão presas ao fim, que não 
pode deixar de ser fim público. Ao agir, o administrador tem de pôr de lado os interêsses particulares, que ficam dominados pelo interêsse público, única bússola que o orientará na edição do ato administrativo ou na concretização das operações materiais da Administração.

As sujeições, exorbitantes ou derrogatórias do direito comum, presentes na relação jurídico-administrativa, constituem o regime jurídico de direito público, caracterizado, precisamente, por aquêles pontos negativos, que se colocam ao lado dos pontos positivos, constituidos pelas prerrogativas.

A vinculação ao fim; a obrigatoriedade de concurso para certos cargos; o regulamento geral e impessoal para o preenchimento de vagas, no funcionalismo; a obrigatoriedade da abertura de concorrência pública para serviços, obras e fornecimentos; o princípio da igualdade dos usuários - são, em seu conjunto, sujeições ou limitações que tolhem a atividade do administrador, em prol dos administrados.

Prerrogativas de potestade pública e sujeições de potestade pública constituem os pontos salientes para o delineamento do regime jurídico de direito público, que informa as atividades e providências das pessoas jurídicas públicas.

Vinculação ao fim - fim de interêsse público - è o primeiro traço que caracteriza o regime jurídico das sujeições da Administração.

O fim, elemento integrante do ato administrativo, reside no resultado que o objeto do ato deve atingir. Por isso, o ato não pode ser viciado ou defeituoso, o que traria, como efeito, o desvio de poder, que ocorre quando a autoridade usa o poder que o Estado lhe outorga para atingir fins diversos daqueles assinalados pela leis e pelos regulamentos.

Ultrapassada a apreciação de seu campo, ou perseguido outro fim, estranho ao seu desiderato, não há dúvida, 
então, de que há defeito na subtância do ato (Forsthorf Ernst, Lehrbuch des Verwaltungsrechts, I,Allgemeiner Teil, 1958, pág. 86 e Huber Ernst Rudolf, Wirtschaftsverwaltungsrecht, 2. ${ }^{\text {a }}$ ed., 1958, vol. II, pág. 657 - Die gerichtliche Prüfung der Ermessensfehler).

Provado o desvio de poder, o que é extremamente difícil, em razão, primeiro, da presunção de legitimidade que reveste os atos administrativos, depois, porque a Administração ocupa uma posição privilegiada nas relações com o administrado, o ato é nulo, em virtude do defeito capital que o inquina.

Em todos os países, a prerrogativa da sujeição do administrador ao fim público do ato é protegida, culminando, quando desrespeitada, com a nulidade da medida, bem como, em inúmeros casos, com a responsabilização, penal e patrimonial, da autoridade editora do ato.

A seleção do funcionalismo revela outro aspecto da sujeição do Estado que não pode escolher o pessoal administrativo por impulsos pessoais, mas através de meios objetivos, científicos, como, por exemplo, o concurso.

Observa-se também outro aspecto da sujeição da Administração, no caso das concorrências públicas para a celebração de acôrdo com particulares. Comprando, vendendo, dispondo de seus bens, ajustando normas para a execução de obras públicas ou de serviços públicos, o Estado recorre ao procedimento da concorrência pública, momento preliminar do contrato administrativo.

A concorrência pública, a que se sujeita a Administração, permite que se atenda ao princípio da moralidade pública, impedindo os favoritismos.

A igualdade dos usuários diante dos serviços públicos, oferecidos pelo Estado, é outra sujeição a que se vincula a Administração.

Nenhum usuário receberá tratamento especial diante dos serviços públicos, fornecidos pelo Estado. Se a tarifa é $\mathrm{x}$, todos receberão o fornecimento, mediante o pagamento 
do mesmo quantum. Nenhuma isenção, nenhum abatimento, nenhum tratamento diverso, melhor ou pior, enfim, em situações iguais, os usuários podem exigir que a Administração lhes dispense igualdade de tratamento.

10. Regime jurídico das prerrogativas e sujeiçôes da Administração.

A doutrina clássica aceitava como ponto pacífico que a ação administrativa se caracterizava pela desigualdade manifesta entre a Administração e os administrados, pela existência, em favor daquela, de podêres que êstes últimos não tinham.

Tais proposições são hoje tomadas com reservas: é ponto assente que, em nossos dias, os meios exorbitantes ou derrogatórios do direito comum consistem, como acentuamos, não sòmente em prerrogativas, mas também em sujeições (WeIL Prosper, Droit administratif, 1964, pág. 44).

As prerrogativas de potestade pública estão presentes nos vários setores em que se desdobra o direito administrativo.

Pelas prerrogativas revela-se a presença do poder na ação administrativa, bem como por êsses privilégios é que o direito administrativo se articula com os demais ramos do direito público e, em especial, com o direito constitucional, visto que as prerrogativas são a expressão da parte da soberania do Estado atribuida ao poder governamental (WeIl Prosper, Droit administratif, 1964, págs. 44-45 e Veder,, Georges, Droit administratif, 4. ${ }^{a}$ ed., 1968, pág. 19).

Traçar o regime jurídico das prerrogativas e sujeições da Administração é apontar um a um os pontos máximos e mínimos, os atributos positivos e negativos, é delinear o lugar geométrico que a Administração ocupa, sempre que toma iniciativas, na sua condição vertical, no mundo administrativo. 
O Estado e, em geral, tôda pessoa jurídica pública, da qual a Administração constitui um particular momento, tomam iniciativas no mundo, iniciativas que se concretizam assim que se efetiva a relação jurídico-administrativa. Nesses momentos, a Administração ora é dominus, ora é servus, ora se projeta com uma amplitude máxima de movimentos, ora é restringida ou limitada, ficando o arbítrio ou vontade do administrador, sob o impacto de normas rígidas, que lhe circunscrevem a movimentação.

Ao lado da potestas publica ou dominica potestas há a servitus publica: potestade pública e servidão pública.

As prerrogativas e sujeições, que regem a atividade da Administração, formam um quadro singular, com índices típicos e inconfundíveis - o regime jurídico público, exorbitante e derrogatório do direito comum, que se coloca na base das pessoas jurídicas públicas.

Esse regime jurídico público, que regula os diferentes momentos da ação administrativa é, pois, constituído de altos e baixos, de majorações e minorações, de maximizações e minimizações, de senhorio e servidão, de potestade e sujeições, informando cada ato administrativo ou cada operação da Administração, a tal ponto que o administrador caminha por um iter e desenvolve um programa, que não é o seu, mas o do interêsse público, alicerçando-se em cada pronunciamento, no pedestal privilegiado que lhe dá sua condição de potestade pública, mas ao mesmo tempo, ficando circunscrito a uma série de ligamentos ou sujeições que lhe policiam a vontade, lembrando-lhe a cada instante o princípio da indisponibilidade dos interêsses públicos. 